\title{
WHAT SOW THE SEEDS OF HARDSHIP FOR THE POOREST OF THE POOR? TOWARDS INCREASING THE PERFORMANCE OF INFORMAL SECTOR IN WAR AFFECTED REGIONS OF SRI LANKA
}

\author{
F. H. Abdul Rauf \\ Department of Management \\ South Eastern University of Sri Lanka \\ hansiyar@yahoo.com \\ Rukshan Bernard Lovell \\ Postgraduate Student \\ Faculty of Management and Commerce \\ South Eastern University of Sri Lanka \\ rukshanlovell@gmail.com
}

\begin{abstract}
Less performance of informal sector among the poorest of the poor in the war affected regions in Sri Lanka has been caused by many reasons. Findings of an exploratory study and the factor analysis revealed four important factors namely training and skills, education, social and economic. As the extension of the exploratory study, to test this prediction empirically with a larger sample size, the present study applied a survey method using a questionnaire especially designed based on the initial exploratory study which was conducted inductively. A sample of 300 women headed households engaged in the informal sector participated in this study. The results indicates these four factors significantly predict the performance of informal sector. More specifically, while, economic factors contribute more to the performance of the informal sector, training contributes less. The study also discussed the implication of findings and area for future research. Based on the findings and conclusions, few recommendations are also made to enhance the performance of women headed households in the informal sector.
\end{abstract}

Keywords: Hardship, poorest of the poor, informal sector, performance, war affected region, Sri Lanka

\section{Introduction}

Performance of informal sector become crucial for the economy of any country. This is especially true for developing countries such as Sri Lanka. As such the contribution of informal sector in Sri Lanka is very significant. According to Sri Lanka Labour Force Survey Annual Report (2014) out of the 8.4 million people who are employed in Sri Lanka and the back bone of the country's economy five million of them are falling in to the informal sector so the contribution of informal sector employment to the total employment is about 59.5 percent and 89.7 percent of agricultural employment involves with informal sector 
Table 1: Distribution of formal/ informal sector employment by gender for the year 2014

\begin{tabular}{|l|l|l|l|l|l|l|}
\hline \multirow{3}{*}{ Gender } & Total & \multicolumn{5}{|l|}{ Sector } \\
\cline { 2 - 7 } & & \multicolumn{4}{|l|}{ Formal } & \multicolumn{4}{|l|}{ Informal } & \\
\cline { 2 - 7 } & No & $\%$ & No & $\%$ & No & $\%$ \\
\hline Total & $8,423,994$ & 100.00 & $3,408,554$ & 40.5 & $5,015,450$ & 59.5 \\
\hline Male & $5,548,131$ & 100.00 & $2,804,124$ & 37.6 & $3,464,008$ & 62.4 \\
\hline Female & $2,875,862$ & 100.00 & $1,324,420$ & 46.1 & $1,551,442$ & 53.9 \\
\hline
\end{tabular}

Source: Sri Lanka Labour Force Survey Annual Report - 2014

employment, majority of both males and. females are employed working in the informal sector. But however when comparing the women employment out of the 2.8 million women who are employed $53.9 \%$ of them are in informal sector. This is presented in Table 1

Engagement of females in small business and informal sector is comparatively higher. However, it seems that the performance of this sector is not to the expected level due to many reasons. According to Fridah (2012) it is evident that, women tended to operate smaller enterprises than men. According to some studies the evidence have been provide of female underperformance (Brush 1992; Rosa et al., 1996), but in some other studies they do not find gender-based differentials (Du Rietz \& Henrekson, 2000; Bardasi, 2007). So the study findings depend in part on what measure of performance is used and what are the other factors controlling the outcome. A study conducted by ILO (2003) regarding women in growth enterprises found that 70 per cent of the women entrepreneurs currently engaged in small enterprises had started them as microenterprises and grown them over time. There are several evidence showing that female owned enterprises are smaller in terms of employment, sales, and assets than male-owned enterprises (Coleman, 2007; Robb, 2002). Some studies also indicate that firms owned by men are more profitable than women owned business. Bosma et al. (2004) found that male Dutch business owners outperformed women in terms of profit. Robb and Wolken (2002) studied a sample of white-owned small businesses in the U.S. and show that women owned businesses generate only $78 \%$ of the profits generated by maleowned businesses.

The case still worse among women headed households. It is often presumed that women and children suffer greater poverty than in households which are run with the help of a male-headed arrangement by this the most common phrase which is spoken among people is that female-headed households are the 'poorest of the poor'. In addition, this might not only compromise the physical well-being of children, but other privations on emotional, psychological and social wellbeing of the family. Beyond affecting young people in the short-term, these are also deemed to sow the seeds of future hardship (Chant Sylvia, 2007). This has been supported by many evidence. 'Women-headed households are overrepresented among the poor in rural and 
urban... developing and industrial societies' (Bullock, 1994, p17-18). 'One continuing concern of both the developing and advanced capitalist economies is the increasing amount of women's poverty worldwide, associated with the rise of female-headed households'(AcostaBelén \& Bose, 1995, p.25). 'What is clear is that in many countries women tend to be over-represented in the ranks of the "old" or structural poor, and female-headed households tend to be among the most vulnerable of social groups'. Graham (1996) p3. '...the number of female-headed households ... is increasing and...they are more vulnerable and face more discrimination because they are poor and also because they are man-less women on their own'. Bibars (2001) p 67. 'Households headed by females with dependent children experience the worst afflictions of poverty ... Female headed households are the poorest'. Finne (2001) p 8.

\section{Women headed households (WHH) in Sri Lanka}

WHH are identified as households with female headship where women are financially responsible for their families, are the main economic contributors, the key decision makers and household managers while they manage the household economies on behalf of an absent male head. When considering WHH this could take the form of having a male in the family but he could be in a position unable to help to the economy of the family due to various reasons like disability or alcoholism and sickness. For purposes of this study WHH refers to being responsible for providing for the entire household, economically independent and the absence of a male head in the household caused by death, divorce, separation, disability and missing.

According to the household survey, one member from usually living members of each household as the head of the household and therefore the number of households equals the number of heads of the households. According to general cultural practices of the country, in most of the households, a male, usually the husband or the father of the family is selected as the head of the household. Out of 5 million households, in Sri Lanka, 1.1 million households or $23 \%$ of the households are female headed households. (Household Income and Expenditure Survey, 2013).

\section{Factors influencing the performance of informal sector}

Although many efforts are made to improve the performance of informal sector by many organizations, the performance of it did not reach to its optimum level due to many factors. When going through literature a synchronized characteristic is seen among informal sector and micro, small enterprises and the factors affecting/ influencing the performance of the MSE's might also have an impact on the informal sector so this study reviewed literatures containing factors affecting the MSEs.

\section{Skills, Training Factors and Performance}

Many researchers have identified training factors as an important element influencing the performance of an enterprise at any level. Samiti (2006) and Tan (2000) categorized the fundamental factors that affect entrepreneurs is lack of marketing knowledge and lack of 
business training. Business assistance and support service were identified by Gemechis (2007) and Hisrich (2005) as crucial factors that affect entrepreneurial success. According to ILO (2003), SMIDEC (2004) Lack of entrepreneurial, managerial and marketing skills were identified as factors affecting the women MSEs. A similar study by Walelign and Wondimu (2002) shown that women entrepreneurs in MSEs in Amhara region are constrained by the lack of sufficient training.

Eshetu and Zeleke (2008), ILO (2003) found that women entrepreneurs in Ethiopia had shortage of technical skills and poor managerial skills and women entrepreneurs in Ethiopia lack on marketing skills on knowing how to market their products. Mahbub (2000) identified that women often are unable to market their goods and services strategically because of the lack of access to training and experience in how to react in the market place and to explore new markets they requires expertise, skills and knowledge. Schorling (2006) found the most pressing problems facing MSEs in Ethiopia are lack of qualified human resources.

According to Fridah (2012) due to lower education levels women entrepreneurs lack entrepreneurship skills which is a disadvantage to women entrepreneurs. ILO (2008) also found that less education level was creating a barrier in accessing training and other business developments services. Common wealth secretariat (2002) found that training for women is another weakness to the microenterprise success so they are less well equipped to manage a business. Namusonge (2006) noted that entrepreneurial education (entrepreneurship training) and training play a key role in stimulating entrepreneurship and self-employment.

Nugundu (2012) mentioned that in Kenya several interventions specifically establishment of a Women's University of Science and technology, creation of business development services (BDS) and setting up a regional centre for enterprise development (RCED) are being carried this will ensure the training support is given to this women. Cooper et al. (1992) studied many factors which has an impact on business performance and out of that Human capital (level of education, skills) were identified as one main requirement.

\section{Economic Factors and Performance}

When considering the second variable which is economic factors there are many literature supporting the fact that economic factors has an influence in the enterprise performance Samiti (2006), Tan (2000) categorized the fundamental factors that affect entrepreneurs in to two broad categories and was identified as economic. The economic factors include the following, lack of access to raw material, lack of capital or finance, lack of access to the market and poor infrastructure. Schorling (2006) identified the most pressing problems facing MSEs in Ethiopia are lack of market, lack of capital, shortage of supply of raw materials, no proper working premises and marketing problems.

Longenecker, et al. (2006) found that improper financing have been posited as the main causes of failure of small enterprises. Some studies (Oketch, 2000; Tomecko \& Dondo, 1992) found that lack of credit was identified as one of the most serious constraints hindering the 
SMEs development. ILO (2003), SMIDEC (2004) found that difficulties in accessing financial resources and the lack of capital were challenges to enterprises. A similar study by Walelign and Wondimu (2002) showed that women entrepreneurs in MSEs in Amhara region are constrained by lack of finance / capital, lack of market, lack of infrastructure facilities and shortage of the supply of raw materials. Eshetu and Zeleke (2008) stated that, women entrepreneurs in Ethiopia find difficulty in obtaining loan from commercial banks. Additionally, ILO (2003) found the following many constraints of women entrepreneurs in Ethiopia they are inadequate infrastructure, stiff competition (marketing problems), lack of suitable location or sales outlet (Infrastructure) shortage of raw materials, and shortage of working capital. Fridah (2012) mentioned that Micro-enterprises are specifically vulnerable to competition from counterparts who introduce new products or services, or improve their production processes, lacking the resources to compete in the markets. Jaiyeba (2010) found that lack of marketing skills is a hindering factor for MSEs. ILO (2008) found in a study conducted in Ethiopia, the United Republic of Tanzania and Zambia that women entrepreneurs lack access to formal finance and rely on loans from family and community, the lack of access to titled assets that can be offered as collateral for loans adversely affects the growth of their enterprises.

Mahbub (2000) identified that access to finance is a major issue for women MSEs. Particularly accessing credit, for starting an enterprise. Mainly this because women often lack collaterals. Mahbub (2000) found the unwillingness to accept household assets as collateral and negative perceptions of female entrepreneurs by loan providers make it hard for female to obtain a loan. According to WB (2009) statistics show the average level of collateral required for a loan is $\mathbf{1 7 3 \%}$ in 2006 by banks is one of the highest in the developing world. It is more difficult to access finance for capital expenditure than for working capital. According to a survey carried out by the World Bank in the micro, small medium and large firms' access to finance was rated as one of the top three problems where $60 \%$ of firms responded supported it.

According to IFC report a significant proportion $(40 \%)$ of firms interviewed said that insufficient access to finance was a major obstacle when starting or expanding their business. Lack of access to finance represented a key constraint for three reasons: Firms did not have enough resources to start at a bigger scale or expand rapidly; Interest rates were too high; Business slowdown increased financial needs or made it difficult to repay loans. A quarter of the companies surveyed said difficulties in repaying loans were due to: The European financial crisis; higher loan costs; Competition; Delayed client payments; Macroeconomic conditions. A report indicates that, lack of access to finance and unavailability of skilled workers, and especially during crises, smaller businesses are more vulnerable to shocks and have greater problems accessing finance than larger firms (IFC, 2012, p.6)

UNECE (2004) cited that women-owned MSEs are often unable to market their production or goods. They are unable to market their goods 
and services strategically. Women's SMEs often complaining about the lack of demand for their products. They often produce small amounts, due to this they are limited to the local village markets, where the market for their products and services are already saturated, thus become dependent on the middle traders who buy their products at relatively lower than the market price. According to Athanne (2011) women entrepreneurs are facing the greatest barrier in accessing finance due to collateral requirements. Most women who undertake businesses in the rural areas who are in need for financing lack the needed collateral to assist them to get a bank loan. Zororo (2011) and Brush (1992) found that financial aspects of setting up a business are without doubt the biggest obstacles to women.

According to the Common wealth secretariat (2002) getting the needed finance to start a new business or to grow an existing one is a difficult challenge. Lack of information to get a loan, lack the needed collateral and face biased laws are issues which should be cleared. Kinyanjui (2006) recorded that some entrepreneurs felt that it was difficult to obtain loans as they had to show credit records while they did not fully understand the requirements needed. Stevenson and St-Onge (2005) also stated that formal financial support is seen to be too expensive for many women entrepreneurs and hence they treat this as a last resort. According to Fridah (2012) Micro-enterprises are specifically vulnerable to competition from counterparts who introduce new products or services, or improve their production processes, lacking the resources to competition in the markets said to be major challenges. Nugundu (2012) also found that resources were not accessible to the informal enterprises and it was only available to few people. Becker (2004) affirms that the informal economy enterprises cannot access resource institutions generally available to the formal economy such as banks and other financing institutions,

Blunch et al. (2001) add that people engaged in the informal sector face a many barriers like, limited or lack of access to resources and markets as well as to land and physical infrastructure. Also Nugundu (2012) found that capital investment was a great challenge as the participants lacked financial resources to expand and invest in their small or informal enterprises, and as a result their businesses were backsliding and some were stagnant. Blunch et al. (2001) verified that financial capital investments in the informal sector tend to be low and are relatively scarce. Canagarajah and Sethiraman (2001) Competition in the market is another economic challenge faced in the informal sector this arises because there are few entry barriers, and this competition has also kept the income of those involved at a minimum, most of which is essentially a return on their own labour.

AccordingtoO'NeilandViljoen(2001)identified women entrepreneurs experienced problems in accessing finance due to lack of business and management experience. Yousefpour et al. (2012) quoted lack of consumable materials and financial difficulties as barriers. ILO (1998) categorized Infrastructure and access to credit as barriers to women's entrepreneurship. The role of rural women entrepreneurs in Iran Saber (2002) studied to investigate the limitations and found financial, physical, marketing and 
sales were barriers. Karimi (2005) found financial problems as one of the main barriers to entrepreneurial women. Mirghafoori et al. (2007) also identified six barriers affecting women entrepreneurs' entrepreneurship in Yazd province (Iran) out which financial was one of them and it was the most important barriers in women's entrepreneurship.

Also, in a study conducted by Momayez et al. (2013)with title"Investigatethefactorsaffecting women entrepreneurship development" Economic factors were identified as one of the influencing factor. Sathiabama (2010) showed that marketing for their products was one of the barriers facing women entrepreneurs. According to Nugundu (2012) the efforts being made to empower women entrepreneurs in MSEs in Kenya several interventions are being carried out by a number of stakeholders to ensure that the sector plays its role fully. The formation of women enterprise fund (WEF); finance from mainstream commercial banks; informal financial support; access to infrastructure and donor initiatives are some of the activities taken forward. On the other hand Thibault et al. (2002) suggest that performance of business could be influencing attributed to financing,

\section{Social Factors and Performance}

When considering the factors influencing enterprises, many researchers have identified social factors as an important element influencing the performance of an enterprise at any level. Samiti (2006) and Tan (2000) categorized the fundamental factors that affect entrepreneurs in to two broad categories and one was social. The social factors include the following: Having limited contacts outside and class bias, Relations with the work force, Lack of social acceptability, Attitude of other employees, Society looks down upon.

In addition to this, Gemechis (2007), Hisrich (2005) and ILO (2009) added that social and cultural attitude towards youth entrepreneurship as crucial factors that affect entrepreneurial success. According to Amyx (2005), one of the most significant challenges is the negative perception towards small and micro enterprises prospective customers feel that small businesses or micro business don't have the ability to offer quality services. According to ILO (2003), SMIDEC (2004) lack of mutual recognition schemes Language barriers and cultural differences; discriminatory regulatory practices are faced by women MSEs. A similar study by Walelign and Wondimu (2002) showed that women entrepreneurs in MSEs in Amhara region are constrained by Cultural influence.

A study conducted in Ethiopia, the United Republic of Tanzania and Zambia by ILO (2008) identified that women often experience harassment in registering and operating their enterprises. Desta Solomon (2010), ILO (2006), The Centre for Women's Business Research in the United States as cited in UNECE (2004) and Mahbub (2000) identified as women may fear or face prejudice or sexual harassment they are restricted in their ability to travel to make contacts. Desta Solomon (2010), ILO (2006), found due to various factors linked to either their family responsibility or cultural practices women extremely experience limited mobility. Training session trainers being men is a major barrier for women entrepreneurs (because women prefer women trainers and husbands do 
not like women to be trained by men trainers) Desta Solomon (2010).

According to Mahbub (2000) when considering most of the existing networks they are male dominated and sometimes not particularly welcoming to women but prefer to be exclusive somehow if a woman does get into these networks, she often finds it hard because most of these network activities take place after regular working hours which constrains her family commitments which brings other problems in to her family life. When it comes to access to policy makers most women have little representation on policymaking bodies or access to policymakers. Men or large companies are more able to easily influence policy and have access to policymakers UNECE, (2004). Women micro-entrepreneurs are often not taken into account by policymakers ILO (2006).

OECD (2002), ILO (2008) found gender inequality and conflicting gender roles as key factors affect women entrepreneurs' performance exclusively in developing continents like Africa. In addition to that Nugundu (2012) found that women headed households in the informal sector enterprises are not registered with governing authorities and they lack any form of protection and representation. According to Athanne (2011) business licensing is an issue for many women entrepreneurs who perceive the process as lengthy and complex which is a social discrimination. It was also mentioned when it comes to women owned enterprises they find that they are not taken seriously by their employees, especially in non-traditional sectors, and have to make a special effort to win their respect this kind of situations are created by social factors. Ahmad et al. (2011) revealed that women are overloaded with business and family responsibilities and may not have the time to join beneficial associations, Common wealth secretariat (2002) adds women may not be able to take advantage of business training because when it is available, it is held at a time when they are looking after their family which is a social factors hindering the enterprise. In the rural setup mostly education preference were given to boys, thus the educational level of most women entrepreneurs is very low, creating a barrier to them accessing training and other business developments services which is also a social factor. (ILO 2008).

Becker (2004) emphasizes that the informal economy enterprises cannot access resource institutions generally available to the formal economy. Sindhu, Narayan and Geethakutty (2003) identified that social recognition flexibility, personal freedom and security are motivators for women entrepreneurs. Fridah (2012) mentioned that the most important barrier for rural women entrepreneurs are society's attitude towards women's employment. Yousefpour et al. (2012) found that rural women entrepreneurs are facing with problems such as cultural, excessive dependence on intermediation and family constraints. According to Alidoost et al. (2012) cultural barriers are the most obstruct for women's employment rate in Iran.

According to in Hasheminejad (2005) discriminatory behaviour of the lender, the perception that women's level of education is low and do not have the ability to introduce 
guarantee prevents female entrepreneurs to get loans and banking facilities and he added social status for women entrepreneurs, especially those women who are trying to make business is very difficult as they face legal barriers and social discrimination measures. ILO (1998) has found social and cultural barriers like: negative attitude toward women at work and fewer opportunities in the formal sector of the economy to improve their skills as discrimination under social factors.

The role of rural women entrepreneurs in Iran Saber (2002) studied to investigate the limitations, the study finding were divided into three parts, where Individual barriers: barriers that arise from personal and family constraints of women entrepreneurs and environmental barriers: barriers which are mainly cultural barriers and social were among them. Butter and Moor (1997) study respondents have stated that gender was a factor to lack of their entry into social circles. Karimi (2005) found disputes between members and discrimination against women as the main barriers to entrepreneurial women.

Mirghafoori et al. (2007) identified six barriers affecting women entrepreneurs' entrepreneurship in Yazd province (Iran) where family barriers and cultural - social barriers were among them while the researcher also indicates that cultural barriers and financial barriers in women's entrepreneurship are the most important. Chitsike (2000) found women entrepreneurs in Zimbabwe accessing the resources are faced with more restrictions than men and don't received any support from the legal system. Research of Sathiabama (2010) also showed that factors such as their family responsibilities sometimes prevented access to some of the opportunities.

\section{Education Factor and Performance}

Education is one of the most important factor for any person to service in today's competitive world regarding the informal sector employees to it is the same but when going through the factors influencing the informal sector education has been highlighted as one of the hindering factor for the performance of the informal sector in support to this there are many literature.

Gemechis (2007), Hisrich (2005) and ILO (2009) emphasis added the following as crucial factors that affect entrepreneurial success is entrepreneurship education. As MSEs are business venture is small in size, a simple management mistake is likely to lead to sure destruction of the enterprise so there is no chance to learn from its past mistakes poor management has been posited as one of the main causes of failure of small enterprises Longenecker et al. (2006). Education is one of the factors that impact positively on growth of firms (King \& McGrath, 2002), but when they have less education level it will also tern as a hindering factor. The entrepreneurs with high number of human capital, with good education are able to improve their business to a better situation and able to adapt their enterprises to frequently changing business environments.

According to ILO (2003), SMIDEC (2004) found that lack of accessibility to information, knowledge and lack of quality awareness are challenges that affect MSEs. Walelign and Wondimu (2002) also found that women 
entrepreneurs in MSEs in Amhara region are constrained by lack of information. Eshetu and Zeleke (2008), ILO (2003) found women entrepreneurs in Ethiopia had low level of education. Moreover, a study conducted in Ethiopia, the United Republic of Tanzania and Zambia by ILO (2008) identified that: Women entrepreneurs do not have the same access to networks as men, additionally, ILO (2003) found that lack of market information is a constraint for women entrepreneurs in Ethiopia.

In support of this a review by Desta Solomon (2010), ILO (2006), The Centre for Women's Business Research in the United States as cited in UNECE (2004) and Mahbub (2000) identified since most women entrepreneurs operate on a small scale they often find it difficult to access information, these entrepreneurs are generally not members of professional organizations or part of other networks. These Women have fewer business contacts, less knowledge of how to deal with the governmental bureaucracy and less bargaining power all of which further limit their growth. When considering most of the existing networks they are male dominated by lacking proper networks it denies women of awareness and exposure to good role models.

Schorling (2006) found out of the most pressing problems facing MSEs in Ethiopia lack of qualified Human resources also is among them. Fridah (2012) also mentioned that lower education levels puts women entrepreneurs in Kenya at a disadvantage compared to men, when there is lower education it does not help to acquire the entrepreneurship skills which decreases the chances on having the knowledge needed to excel in business. ILO,
(2008) found that in the rural setup mostly education preference were given to boys, thus the educational level of most women entrepreneurs is very low, creating a barrier to them accessing training and other business developments services. In addition Common wealth secretariat, (2002) also found that lack of sufficient education for women is another weakness to the micro-enterprise success. In addition, women are usually less educated than men, making them less well equipped to manage a business

Namusonge (2006) noted that entrepreneurial education plays a key role in stimulating entrepreneurship and self-employment. According to O'Neil and Viljoen (2001) women entrepreneurs are ill-equipped educationally. According to Matiwane (2005), preparation of budgets, targets and knowledge of business is important for good performance of MSEs but women tend to have little education and experience in starting and managing a business and gaining relevant knowledge can be difficult since they have the double work burden of work and childcare responsibilities. Stel (2007) also found that women are educationally less and well equipped to manage some kinds of businesses.

ILO (1998) had found that educational barriers affect MSEs as relatively women have a lower educational level than men. Mirghafoori et al. (2007) identified barriers affecting women entrepreneurs entrepreneurship in Yazd province (Iran) it was found that six categories of which academic (Education) was among them which had an effect on women entrepreneurship. In a study conducted by Momayez et al. (2013) 
with title "Investigate the factors affecting women entrepreneurship development", result showed that level of education plays a key role. While Lerner and Hisrich (1997) conducted a study on Israeli women entrepreneurs found Human capital (level of education, skills) one of the factors that affect the performance. As presented in the literature review in the previous section, in general performance of informal sector is effected by many factors. This has been interesting topic among scholars and donors in various context in various part of the four important factors, training and skills, education, social and economic matched with the literature review.

As the extension of the study of Rauf and Rukshan (2016), with a larger sample size, to test this prediction empirically, the present study apply a survey method using a questionnaire especially designed based on the initial study by Rauf and Rukshan (2016). As such, this study has developed the following conceptual model and four hypotheses.

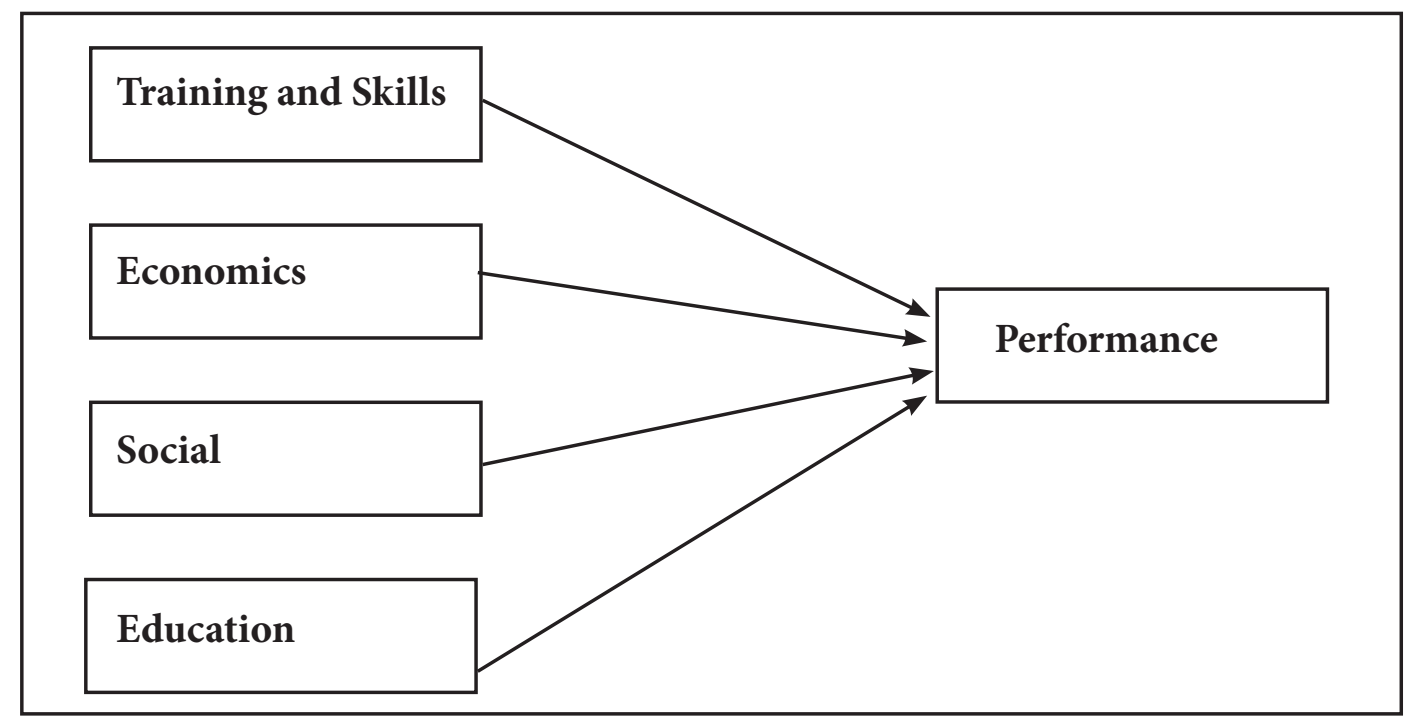

Source: Developed for this study

Figure 1: Conceptual frame work

world. However, only one study is conducted inductively to identify the factors influencin the performance of informal sector in the Sri Lankan context among a sample of women headed households (Rauf \& Rukshan, 2016). The exploratory study and the factor analysis conducted by Rauf and Rukshan (2016) found

$\mathrm{H}_{1}$ : Employees who have more skills would show more performance of Informal Sector.

$\mathrm{H}_{2}$ : The more the difficult in getting the economic factors the lower the performance of informal sector.
$\mathrm{H}_{3}$ : The extent to which social support is received by the informal sector employment influences the performance of Informal Sector.

$\mathrm{H}_{4}$ : Employees who have higher level of education would have higher levels of performance of Informal Sector.

\section{Method}

The questionnaire developed and validated in the study by Rauf and Rukshan (2016) is used for this study. The questionnaire comprised of two sections: Section A comprised the 
demographic characteristics of the participants; Section B consists of five sub-sections which measure: training and skills, economic, social, education and performance. The items in section $\mathrm{B}$ were scored based on five-point rating scale ranging from $\mathrm{N}=$ never to $\mathrm{A}=$ always. All items were originally developed in English and translated into Sinhala and Tamil via a double blind back-translation technique (Brislin, 1980). The scale was again checked to confirm normal distribution. Reliability Cronbach alpha coefficients was 0.76 for section one, 0.84 for sub-section two, 0.83 for sub-section three, 0.79 for subsection four, and 0.84 for sub-section five and 0.79 .

According to the statistics there are 192,772 people living in Vavuniya, out of these people $53 \%$ - 102,169 individuals are economically active. In this $61.2 \%$ of individuals 62,527 in number are in the informal sector according to the 2014 labour survey statistics, accordingly this study consider the informal sector the women headed household who are mostly participating in this sector which amounts to 9389 families (according to the Ministry of social welfare Vavuniya district office). This could be divided as Vavuniya Town 6140 families, Vavuniya South 906 families, Vavuniya North 822 families and Vangalachettikulam 1521 families. By using stratified sampling method out of the population a sample of 300 families are selected. The sampling is drawn in the following manner.

Table 2: Sample break down

\begin{tabular}{|l|l|c|}
\hline Name of Division & Sample calculation & Sample \\
\hline Vavuniya Town & 6140 families /9389 families x 300 & 196 \\
\hline Vavuniya South & 906 families /9389 families x 300 & 29 \\
\hline Vavuniya North & 822 families /9389 families x 300 & 26 \\
\hline Vangalachettikulam & 1521 families /9389 families x 300 & 49 \\
\hline Total & & 300 \\
\hline
\end{tabular}

Source: Vavuniya district statistical data, 2015

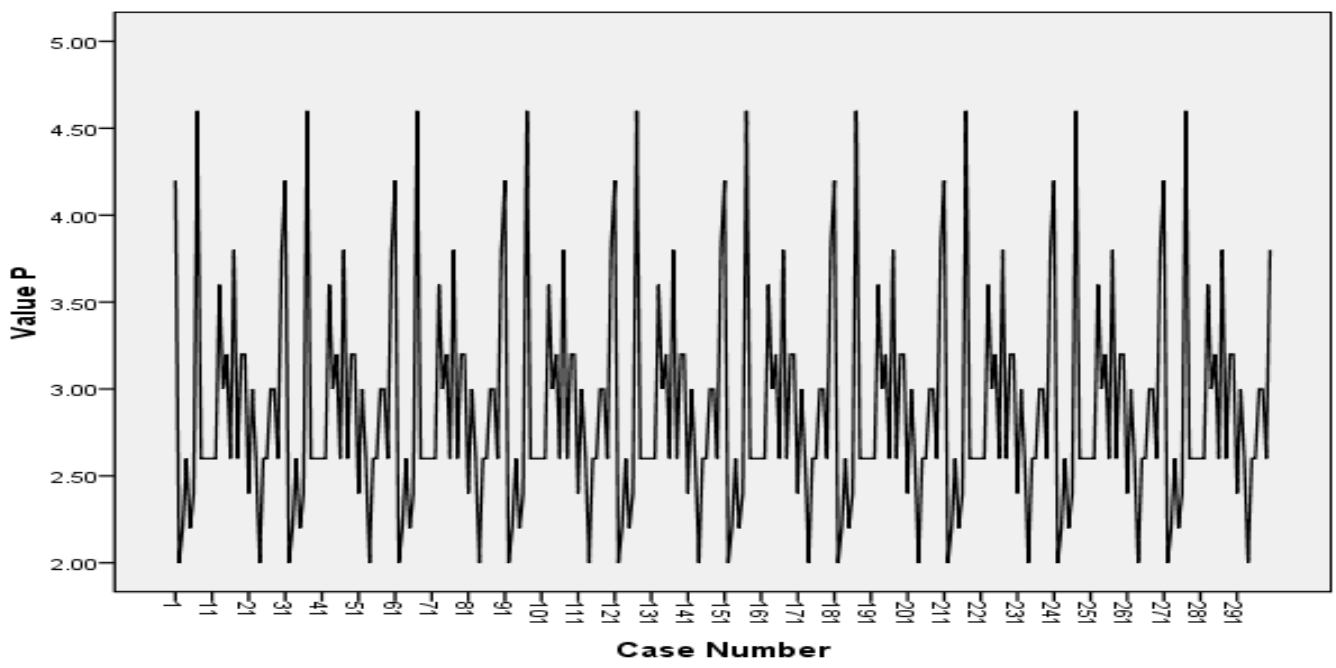

Figure 2: Pattern of performance by the respondents 
The Figure 2 shows that there is a fluctuation in the performance among respondents. These fluctuations are determined by its predictors. As such the present study has hypothesized four factors as determinants of the performance of the informal sector. Hypotheses are tested using correlations and regression analysis.

The purpose of correlation and regression analysis is to analyze the relationship among variables and measure the strength of the linear relationship between the variables. According to Swanson and Holton (2005), it is the most popular statistical technique for hypothesis testing and is used to measure the naturally occurring levels of the variables to predict the score on the dependent variable. The advantage of this regression analysis method often cited is its ability to test and reveal relationship between the dependent variable and independent variables with different levels of significance.

Correlations between the independent and dependent variables of this study are given in Table 3. This explains the inter correlation among the independent variables and dependent variables and between dependent and independent variables. Therefore, researcher infers that moderate and strong correlation exists between independent variables i.e. Training, Economic, Social, Education and dependent variables i.e. Performance.

The $r$ values between Training and Performance is 0.845 , Economic and Performance is 0.899 , Social and Performance is 0.841 , and Education and Performance is 0.893 (all $>0.3$ ). Thus Performance is associated with all Training, Economic, Social, and Education. The $r$ value between other variables are less than 0.90. Therefore, no multicolliniarity. The results of the correlations reveals that there is a relationship between independent and dependent variables. Variables such as Training, Economic, Social, and Education are significantly associated with dependent variable Performance. It is because of the fact that at $1 \%$ significant level, all independent variables are significantly correlated with dependent variables i.e. Performance. Hence,

Table 3: Correlations among studied variables

\begin{tabular}{|c|c|c|c|c|c|c|}
\hline \multicolumn{7}{|l|}{ Correlations } \\
\hline & & TS & $\mathrm{E}$ & S & ED & $\mathrm{P}$ \\
\hline Training & Pearson Correlation & 1 & & & & \\
\hline Economic & Pearson Correlation & $.819^{* *}$ & 1 & & & \\
\hline Social & Pearson Correlation & $.725^{* *}$ & $.757^{* *}$ & 1 & & \\
\hline Education & Pearson Correlation & $.884^{* *}$ & $.878^{* *}$ & $.789^{* *}$ & 1 & \\
\hline Performance & Pearson Correlation & $.845^{* *}$ & $.899^{* *}$ & $.841^{* *}$ & $.893^{* *}$ & 1 \\
\hline
\end{tabular}

Source: Survey Output 
Table 4: Model Summary

\begin{tabular}{|c|c|c|c|c|c|c|c|c|c|c|}
\hline \multirow[b]{2}{*}{ Model } & \multirow[b]{2}{*}{$\mathrm{R}$} & \multirow{2}{*}{$\begin{array}{l}\mathrm{R} \\
\text { Square }\end{array}$} & \multirow{2}{*}{$\begin{array}{l}\text { Adjusted } \\
\text { R Square }\end{array}$} & \multirow{2}{*}{$\begin{array}{l}\text { Std. Error of } \\
\text { the Estimate }\end{array}$} & \multicolumn{5}{|c|}{ Change Statistics } & \multirow[t]{2}{*}{ Durbin-Watson } \\
\hline & & & & & $\begin{array}{l}\text { R Square } \\
\text { Change }\end{array}$ & \begin{tabular}{|l|} 
F \\
Change
\end{tabular} & df1 & df2 & $\begin{array}{l}\text { Sig. F } \\
\text { Change }\end{array}$ & \\
\hline 1 & $.845^{\mathrm{a}}$ & .713 & .712 & .32747 & .713 & 741.417 & 1 & 298 & .000 & \\
\hline 2 & $.919^{\mathrm{b}}$ & .844 & .843 & .24217 & .130 & 247.912 & 1 & 297 & .000 & \\
\hline 3 & $.940^{c}$ & .884 & .883 & .20870 & .041 & 103.891 & 1 & 296 & .000 & \\
\hline 4 & $.943^{\mathrm{d}}$ & .890 & .888 & .20421 & .005 & 14.178 & 1 & 295 & .000 & 2.150 \\
\hline
\end{tabular}

\section{Sourse : SPSS output}

it could be concluded that Training, Economic, Social, and Education are contributing to the Performance of the informal sector among women headed households. In an attempt to examine the relationship between independent variables and dependent variables, this study performed regression analysis as well. Initially a total model, that is all independent variables as a composite variable regression was carried out.

The R-Square value of 0.890 reveals that the model accounts for $89 \%$ of variance in the $\mathrm{P}$, a very good model with a $\mathrm{p}$-value of less than 0.001 . The Durbin- Watson 2.150 which is almost 2. ANOVA table reveals that the overall significance of the model is good with $p<0.05$.

The equation for the model is, $\mathrm{P}=0.103+$ $0.139(\mathrm{TS})+0.395(\mathrm{E})+0.283(\mathrm{~S})+0.204$ (ED). Accordingly, education factor has most significantinfluencethan otherfactors. Thesocial factor takes the second place in its significance. Model 1, which included only Training, accounted for $71 \%$ of the variance (Adjusted $\mathrm{R} 2=0.713$ ). The inclusion of Economic into model 2 resulted in an additional 13\% of the variance being explained ( $\mathrm{R} 2$ change $=0.13$ ). The third model also included Social which resulted in an additional $4 \%$. Of variance

Table 5: Coefficients of the Study Variables

\begin{tabular}{|c|c|c|c|c|c|c|c|}
\hline \multirow{2}{*}{ Model } & \multicolumn{2}{|c|}{$\begin{array}{c}\text { Unstandardized } \\
\text { Coefficients }\end{array}$} & \multirow{2}{*}{$\begin{array}{c}\begin{array}{c}\text { Standardized } \\
\text { Coefficients }\end{array} \\
\text { Beta }\end{array}$} & \multirow{2}{*}{$\mathrm{T}$} & \multirow{2}{*}{ Sig. } & \multicolumn{2}{|c|}{$\begin{array}{c}\text { Collinearity } \\
\text { Statistics }\end{array}$} \\
\hline & B & Std. Error & & & & Tolerance & VIF \\
\hline \multirow{2}{*}{$\begin{array}{l}1 \\
\text { (Constant) } \\
\text { TS }\end{array}$} & .103 & .058 & & 1.762 & .079 & & \\
\hline & .139 & .042 & .139 & 3.277 & .001 & .209 & 4.777 \\
\hline $\mathrm{E}$ & .395 & .042 & .395 & 9.401 & .000 & .212 & 4.715 \\
\hline $\mathrm{S}$ & .283 & .032 & .284 & 8.806 & .000 & .359 & 2.789 \\
\hline ED & .204 & .054 & .200 & 3.765 & .000 & .133 & 4.525 \\
\hline
\end{tabular}

Sourse : SPSS output 
explained $(\mathrm{R} 2$ change $=0.041)$. The final model 4 also included Education which resulted in an additional $.5 \%$ of variance explained (R2 change $=0.005)$. The ANOVA table also report that results for the four models are significant.

Furthermore, analysis are carried out on the basis of respondents' demographic characteristics at individual item basis. The table below shows that majority of the respondents are above 40 age (130). However, the highest performance (mean value 5.00) is obtained for the item 2 (I have an intention to continue the business) of the performance construct. Almost all the respondents have said to continue their business. This imply that more forces should be given to improve the performance of the informal sector as many families are depending on this so for sustainable development this should be focused on. Most respondents are married (100) or widows which stands at (110). However, the highest performance $($ mean $=5)$ is obtained for item 1, 2 and 5 (my business has grown consistently; I have an intention to continue the business and my production has consistently increased) for the unmarried women. This explains that these women are taking care of their families but without the durned of husband or children as this is evident as they have higher mean value for all responses while the married and the divorced are having lesser mean values.

Respondents who have higher education qualifications have an enhanced mean value than the respondents who have lesser education qualification. This is evident that A/L completed respondents had a higher mean value (5.00) for item 2 (I have an intention to continue the business) as well the average mean value is also higher for $\mathrm{A} / \mathrm{L}$ and for $\mathrm{O} / \mathrm{L}$ completed respondents. When considering the first study there were factors as "advertisement improvement" "unity among business associates" "diseases" so these factors also could have an impact in other districts or similarly in Vavuniya district as the researcher had considered only the women headed households but when it comes to overall informal sector there could be these factors also affecting at a considerable level.

Individual and environmental factors are positively correlated with the performance of informal sector among women headed households in the district of Vavuniya in Sri Lanka (Adjusted R Square $=88.8 p=0.00$ ). Results of the regression analysis reveal that factors training and skills, economic, social and education collectively as well as individually positively associated with the performance of informal sector. More specifically training and skills is significantly related to performance of informal sector. Similarly economic, social and education significantly related to performance. ( $\mathrm{R}$-Square)

These findings are consistent with the previous findings. Fridah (2012), Nugundu (2012), Desta Solomon (2010) and ILO (2008) found positive and significant association between these variables. Overall findings supports all hypotheses and all independent variables are best predictors of performance of informal sector. Thus it is revealed that the factors training and skills, economic, social and education are contributing the performance significantly.

This finding has indicated that training and skills, economic, social and education are the most 
important predictor of the level of performance and are the most critical components for securing higher performance among the respondents of this study. Performance can be increased by providing improved skills for the informal sector participants, this could be done through providing short period training programmes at village level to increase their technical skill as well other skills like accounts keeping, creating a business plan, enhancing customer care, but these trainings should be carried without disturbing their informal business as well their family commitments.

More over by increasing the economic factors like improving the infrastructures, improving marketing opportunities specially helping to get access to finance will help the informal sector participants to improve the performance of their informal sector enterprise. Most of the participants had mentioned that this was the most critical factors out of the four and especially the access to finance was the major problem due to no or less collaterals. This is one problem which needs special attention as well rapid solution.

As per the finding social factors also has its influence on the performance level of the informal sector, so by reducing the barriers like barriers at family, barriers at village level and barriers at societies this should be eliminated to improve the performance of the informal sector enterprise. As these effects ones inner soul and ability to perform well, much awareness programmes should be conducted to eliminate such discrimination against women, to have sustainable development as women play equal part in developing a countries economy.
According to the study findings education also has its influence on the performance of the informal sector as it was evident a less educated person finds it hard to manage a business while a person having a higher education level finds it much easier to handle and operate the business, so more emphasis should be given to increase the education level of the participants in the informal sector. However at present the need for education has been realized and mostly all children are been sent to school by their parents other than exceptional cases so the generation who is already in the informal sector has the need to improve their education level, so if some additional basic educational programmes could be conducted specially for the informal sector enterprises it will help the business to perform well, in future if the school syllabus will also have some business generating idea it will help the country to develop rapidly.

\section{Findings and Conclusion}

Realising the effective functioning of the informal sector and its contribution to the Sri Lankan GDP, this study has set out the main objective as to identify factors that influence the performance of the informal sector among the women headed households in the district of Vavuniya Sri Lanka. Keeping the research findings it is evident that the informal sector is been influenced by the four major factors as training, economic, social and education. Through these findings it is able to conclude that, employees who have more skills would show more performance of Informal Sector; the more the difficult in getting the economic factors the lower the performance of informal sector; the extent to which social support is 
received by the informal sector employment influences the performance of informal sector and last but not least employees who have higher level of education would have higher levels of performance of informal sector. To enhance the performance of women entrepreneurs in the informal sector based on the findings and conclusions of the study, the following recommendations are forwarded.

As the major issue identified access to finance, this should be created at an essay access mode. The banks of Sri Lanka though they have good schemas existing, when it comes to the ground level due to the individual perceptions and not wanting to face risk and safe guard their jobs the bank staffs don't tend to motivate MSEs to obtain these loans. This perception should be changed and people should be encouraged to obtain these loans without going into the informal credit schemes which are dangers and expensive due to high interest rates.

The micro credit institutes also should consider their interest rates, as when it is compared with the bank interest it seems very high. Micro credit institutes and banks should give away loans with a grace period which will help the beneficiaries to start or expand their business and then start paying as in most of the case it is the other way before getting the outcome of the investment they start paying for the loan this should be changed as this too burden the person and due to this also some don't obtain for a loan. Collaterals are also another problem for many as especially the poor people don't have that kind of security, so they are unable to get access to finance. Some special systems should be considered. It could be suggested that donors, funding agencies, NGOs or the Government without giving away in kind support they could keep a huge deposit as collateral in the banks and give away loans for these MSEs.

To make the beneficiary serious about their business, business development services could be given by the Government departments as for this purposes there are several departments created namely industrial development board, department of industries, science and technology officer and small industries development department. By this a good feasible business proposal could be created and submitted to the bank and obtain the loan with a grace period and start the business. When income is generated they could start paying the loan. To monitor this system the government officials like human resource development officer, Samurdhi office, women development officer, social service officer, skills development office, Grama Niladharies could contribute.

More over gender awareness programmes should be done at community level to reduce the discrimination of women participating in MSEs. Most of the time due to culture barriers women feel shy to discuss with the male officers their business plans and meeting them on developing a plan to start or improve their enterprise, so in these case if a women is feeling hard every department should have a women officer who could help these women and reduce the discrimination and give these kind of women the opportunity to explore business activities and gradually have counselling and awareness sessions to prepare them to face the customers. Customer relationship training, marketing training financial training should be 
given to all enterprises. Additionally stress relief programmes specially counselling services should be given by the government officials or some major companies as their corporate social responsibility activity could help these women.

Action should be taken to register all enterprises as the informal sector enterprises are afraid to register due to the lack of awareness so this stereotype should be changed and they should understand that they get a voice if they register them self and they get protection form the law. It could be recommend at every divisional level a lawyer or a person fully aware with the legal requirements of the government should be attached to the division where any entrepreneur could obtain legal advice from these officials.

More over all officers at divisional level involved in the business creation and monitoring should be attached to one premises as all services could be obtained at a single location as it has been observed that most of the time a person has to go around to get all needed activities to commence a business activity. To tackle different economic, social/ cultural and legal/ administrative bottlenecks they face, women entrepreneurs should form entrepreneurs associations and register them at the respective divisional or district secretariats

Infrastructure development projects should be done, especially these informal sector enterprises are from the village levels where there is no proper interior roads, electricity as due to this they find it hard to get raw materials as well market their products. Good insurance schemes should be created and all enterprises should obtain an insurance policy as this will give a protection to these beneficiaries as some times due to manmade or natural disasters always the small businesses find it hard to recover.

More marketing linkages should be created especially try to get international linkages for an example some NGOs have got links from outer countries and exporting handmade batik, handicraft items, handloom so these kind of linkages will help some businesses. Vocational training institutes should change their training programmes to meet the demand of the market but most of the training programmes are conducted depending on the equipment available at these institute so market surveys should be carried out and then training programmes planed.

Recognition of prior learning (RPL) system should be given to all enterprise this is a system though a person has not gone to a formal vocational training he could sit for a practical exam and obtain a national vocational qualification (NVQ) this will help him or her to show case his talent as many are requesting certificate to prove a person's qualification before obtaining a service so this will give recognition as well to obtain government projects NVQ certification is a must requirement. To bring about enterprise development to the educational system where children will be getting the idea generated at their young age and they could prepare a career on that field.

Some basic educational programmes should be introduced to enhance the basic education for the informal sector participants who don't have the basic education, this will be a challenging process, as the commitment level could be less 
from the participants however some regret that due to the war and been displaced often they couldn't continue their education so people like this might join and benefit from it. Women entrepreneurs in MSEs in Vavuniya division should share experiences with other entrepreneurs in other division and or towns or districts so that they can learn a lot from best practices of those entrepreneurs. Medical assistance and check-ups should be mandated for employees as this will help the productivity life span increase as well special the hygienic conditions will improve which will help the business activities.

This study will help the society in many ways, as this study has found the factors training and skills, social, economic and education as mostly influencing the informal sector this will help the people who are directly benefiting from the informal sector to concentrate in these factors as it will help them to improve their performance if they give priority and improve these factors. At the same time NGOs and government institutes working in this field could use these findings as a base to prepare future projects. As in the introduction it way mentioned that because not knowing the actual factors influencing the informal sector large amount of money has been spent to help the beneficiaries in this sector so by using these NGOs or the government officials can create a better project to suite the beneficiaries.

This will be an awakening call to the banks and the micro finance institutes as they can understand that their products have not reached the needy. This study would help the government to prepare better plans for the future in developing the informal sector. Finally this study would help the future researcher for literature as many of the studies are been conducted in other countries and not in Sri Lanka so this will be used during studies under the Sri Lankan context as well for general studies. This could be as a guide line as the factors were found from the respondents them self so they could use these factors as well other factors which were eliminated due to less responses for future studies.

As it is evident from the data findings the four factors identified through this study are influencing a major part in the informal sector performance, other factors also could influencing the performance of the informal sector and they have not been identified this will be an option for future studies. At the same time this study has been conducted at the Sri Lankan content in the war affected region where in another country or in another region which was not effected by war might have other factors influencing as this could be considered as for future studies. More over the researcher had selected women headed households as the respondents other respondents might have different opinions this also could be considered for future researches. In the first study the researcher excluded some factors as they didn't have significant respondents supporting them but in other regions these might be the major factor influencing so this also could be considered. Future research could be conducted with additional factors add to these four factors. 


\section{References}

Acosta, B., Edna., Bose., \& Christine (1995). Colonialism, Structural Subordination and Empowerment: Women in the Development Process in Latin America and the Caribbean', Philadelphia: Temple University Press, 15-36.

Ahmad, S. Z., Xavier, S. R., Perumal, S., Nor, M. L., \& Mohan, C. J. (2011). The transition from corporate Careers to business ownership: The case for women entrepreneurs in Malaysia. International Journal of Business Administration, 2 (3), 149

Alidoost, S., Lashgarara, F., Farajollah, H. S. J. (2012). To prioritize barriers in the development of rural women entrepreneurship in Garmsar city, National Conference on Entrepreneurship and business management knowledge based, Mazandaran University.

Amyx, C. (2005). Small Business challenges, the perception problem: Size Doesn't matter, Washington Business Journal, 2(1), 15.

Athanne (2011). Entrepreneurship in Kenya, Nairobi.

Bardasi, E. \& Abay, G. (2008). Unlocking the Power of Women. Chapter prepared for the Ethiopia ICA. Toward the Competitive Frontier: Strategies for Improving Ethiopia's Investment Climate. World Bank, Washington D.C.

Becker, K. F. (2004). The Informal Sector. Stockholm: SIDA, Swedia. Retrieved on December 25, 2015, from http://rru. worldbank.org/Documents/.
Bibars, I. (2001). Victims and Heroines:

Women, Welfare and the Egyptian

State, London: Zed.

Blunch, N. H., Canagarajah, S., \& Raju, D. (2001). The Informal Sector Revisited: A Synthesis Across Space and Time, Social Protection Discussion Paper Series No. 0119. The World Bank. Retrieved 13-122015, from http://siteresources.worldbank. org/socialprotection/Resources/

Bosma, N., Van Prag, M., Thurik, R., \& De Wit, G. (2004). The Value of Human and Social Capital Investments for the Business Performance of Start-ups. Small Business Economics, 23(3), 227-236.

Brush, C. G. (1992). Research on business owners. Past trends, a new perspective and future directions. Entrepreneurship Theory and Practice, 16(4), 6.

Brislin, R.W. (1980). Translation and Content Analysis of Oral and Written Material. In: H.C. Triandis and J.W. Berry (eds.), Handbook of Cross-Cultural Psychology, (vol. 2, pp. 389-444). Boston: Allyn \& Bacon.

Bullock, S. (1994). Women and Work, London: Zed.

Butter, E. H., Moore, D. P. (1997). Women's organizational Exodus to Entrepreneurship: Self-reported Motivations and correlates with success, Journal of small Business Management, 22, 186-192.

Canagarajah, S., \& Sethuraman, S.V. (2001). Social Protection and the Informal Sector in Developing Countries: Challenges and Opportunities, Social Protection Unit Human Development Network the World Bank. 
Chant, S. (2007). Poverty begins at home? Questioning some (mis) conceptions about Children, poverty and privation in femaleheaded households, London school of economics.

Chitsike, C. (2000). Culture as a barrier to rural women's entrepreneurship: experience from Zimbabwe. Gender and Development, $8(1), 71-77$

Coleman, S. (2007). The Role of Human and Financial Capital in the Profitability and Growth of Women-Owned Small Firms. Journal of Small Business Management, 45(3), 303-319.

Cooper, Arnold C., F. Javier Gimeno Gascon, and Carolyn Y. Woo (1994). "Initial human and financial capital as predictors of new venture performances." Journal of Business Venturing, 9: 371-395.

Desta, S. (2010). Desk Review of studies conducted on women Entrepreneurs in Ethiopia. Differences between Femaleand Male-owned Small Businesses, Federal Reserve.

Du Rietz, A. \& Henrekson, M. (2000). Testing the Female Underperformance Hypothesis. Small Business Economics, 14, 1-10.

Eshetu, B. \& Zeleke, W. (2008).Women entrepreneurship in micro, small and medium enterprises: The case of Ethiopia. Journal of international women'sstudies. 10(2), 3-5.

Finne, G. (2001). Feminisation of Poverty, retrieved from http://www.ywca.int/ programs on 20-07-2015.
Fridah Muriungi Mwobobia 2012 "The Challenges Facing Small-Scale Women Entrepreneurs: A Case of Kenya." International Journal of Business Administration 3(2)

Gemechis, T. (2007). Attitude of College Students towards Entrepreneurship: A Case Study of Addis Ababa University and Rift Valley University College. Addis Ababa, Ethiopia. Unpublished Thesis.

Graham, C. (1996). Gender Issues in Poverty Alleviation: Recent Experiences with Demand-based Programmes in Latin America, Africa and Eastern Europe. Issues in Development Discussion Paper (Geneva: International Labour Organisation).

Hasheminejad, A. A. (2005). Development of women's entrepreneurship, Journal of Employment and Entrepreneurship (Growth), 3(12), 4.

Hisrich, R. D. (2005). Entrepreneurship.7th Edition, Boston: McGraw Hill. Retrieved from http://www.csb.uncw.edu/people/ rowej, on 15-09- 2015

ILO (2003). Ethiopian Women Entrepreneurs: Going for Growth ILO Sub regional Office, Addis Ababa, Ethiopia and Women's Affairs Department, Ministry of Trade \& Industry MoTI/WAD in association with In Focus Programme on Boosting Employment through Small Enterprise Development International Labour Office, Geneva

ILO (2006).Vulnerability and young women Entrepreneurs: A case study of Ethiopian Informal Economy. Geneva: International Labour Organization. Retrieved from http://www.cartierwomensinitiative.com, on 16-08-2015 
ILO (2008). Women Entrepreneurs in Kenya. Factors affecting Women Entrepreneurs in Micro and Small Enterprises in Kenya. Geneva. International labour Organization.

Report on Youth Employment Opportunities in Africa (2009). The Impact of Young Women's Vulnerabilities on Opportunities to become an Entrepreneur A case of Ethiopia - ILO/ECA

Jaiyeoba, O. (2010). The Impact of market orientation on SMMEs in the developing economies: a case of Botswana. International Journal of Business Administration. Retrieved from http:// dx.doi.org/10.5430/ijba.v2n3p132, 15-12$\underline{2015}$

Karimi, Z. (2005). The role of government support in expanding entrepreneurship among women: Case Study: women's cooperatives in Mazandaran province, the first conference women entrepreneurs and the challenges facing it, Association of Women Entrepreneurs' manager.

King, Kenneth, \& McGrath, Simon. (2002). Globalization, Enterprise and Knowledge: Education, Training and Development in Africa. Kluwer Academic Publishers

Kinyanjui, M. N. (2006). Overcoming barriers to Enterprise Growth: The experience of MSEs in Rural Central Kenya, Nairobi, Kenya.

Learner, M., Brush, C., \& Hisrich, R. (1997). Israel Women Entreprenuer: An Examination of factors affecting Performance. Journal of Business Venturing 12 (4), 315-339.
Longenecker, J. G., Carlos W. M., William, P. J., Leslie, E. P., \& Joseph A. M (2006). Ethical Attitudes in Small Businesses and Large Corporations: Theory and Empirical Findings from a Tracking Study Spanning Three Decades

Mahbub, U. H. (2000). Human Development Centre, Human Development in South Asia: The Gender Question (Oxford University Press): Karachi.

Matiwane, M. (2005). South African Women entrepreneurship: A burgeoning force in our economy. A special report for SAWEN, an initiative of the DTI group.

Mirghafoori, S. H., Sayadi Toranloo, H., \& Fahimi Hanzaei, S. (2007). Identifying and ranking barriers affecting entrepreneurial activity of women using techniques mcdm: Women Entrepreneurs in Yazd province, Journal of Women's Studies, 1(2), 33-61.

Momayez, A., Ghasemi, S. A., \& Ghasemi, S. F. (2013). Investigate the factors affecting women entrepreneurship development, technology development, Journal of parks and growth centers, 9(35), 5-22.

Namusonge, G.S. (2006). Entrepreneurial Finance and Micro, Small and Medium Enterprises (MSME) Innovation in Kenya. Technological and Industrialization Conference, JKUAT Nairobi

Nagundu. K. (2012). The Contribution of the Informal Economy to the Social and Economic Development of WomenHeaded Households in the Chegutu Urban District in Zimbabwe. 
O’Neil, R.C., \& Viljoen, L. (2001). Support for Female Entrepreneurs in South Africa. Improvement or decline? Journal of Family Ecology and Consumer Sciences. (29), 3744.

OECD (1997). Entrepreneurship and SMEs in Transitional Economies, the Visegrad Conference, OECD Proceedings, Paris. OECD (2002).The Keys for Successful Women Entrepreneurs. The OECD Bologna Process, December 2002.

Oketch, H. O. (2000). Gender equity. In Mullie \& Bokea(Eds). Micro and Small Enterprises in Kenya: Agenda for improving the policy Environment. Nairobi. ICEG.

Rauf, F. H. A. \& Rukshan, B. L. (in press). Context specific determinants of performance of informal sector: A study of factor structure, Journal of Management.

Robb, A. (2002). Entrepreneurship: A Path for Economic Advancement for Women

Robb, A. \& Wolken, J. (2002). Firm, Owner, and Financing Characteristics.

Rosa, P., Carter, S., \& Hamilton, D. (1996). Gender as a Determinant of Small Business Performance: Insights from a British Study. Small Business Economics, 8, 463-478.

Saber, F. (2002). Ways women entrepreneurship development in Iran, Tehran: intellectuals and women's studies.

Samiti, V. (2006). A research study on Entrepreneurial Challenges for SC Persons in India. New Delhi: Planning Commission Government of India Yojana Bhawan.
Sathiabama, K. (2010). Rural Women Empowerment and Entrepreneurship Development. From: http://www. microfinancegateway.org/gm/document1

Schorling, A. (2006). The Involvement of Women and Men in Micro \& Small Enterprises (MSEs) in Nefas Silk Lafto Sub City. Discussion Paper \& Guideline to Construct a Gender-Sensitive .Addis Ababa, Nefas Silk Lafto Sub City.

Sindhu, S. Narayan, E. \& Geethakutty, P. S. (2003). Level of Entrepreneurial Success among Women Entrepreneurs in Agribusiness. Journal of Tropical Agriculture, 41, 41-44.

SMIDEC (2004). SME Performance, Report, Kula Lumpur, Malaysia.

Stel, A., Thurik, R., Verheul, I., \& Baljeu, L. (2007). The Relationship between Entrepreneurship and Unemployment in Japan, Tinbergen Institute Discussion Papers,

Stevenson 1, St-Onge, A. (2005). Support for growth-Oriented Women Entrepreneurs in Kenya. International Labour Organization, Geneva.

Swanson, R. A., \& Holton, E. F. (2005). Research in organizations: Foundations and methods of inquiry.

Tan, J., \& Young, E. (2000). Entrepreneurial Infrastructure in Singapore: Developing a Model and Mapping Participation, Journal of Entrepreneurship. 9(1). 
Temecko. J., \& Dondo, A. (1992). Improving the potential of small scale and informal sector Nairobi: K-REP and GTZ.

Thibault, M., Wilcock, A., \& Kanetkar, V. (2002). An exploratory study of factors influencing sales performance of small and medium -sized enterprises .Proceedings of the Administrative Sciences association of Canada. Winnipeg, Manitoba.

UNECE (2004). Women's Self Employment and Entrepreneurship in the ECE region", background paper prepared by the secretariat for the Regional Symposium on Mainstreaming Gender into Economic Policies, Geneva, and 28-30 January 2004. retrieved on $18-8-15$ from http://www. unece.org/i.

World Bank (2009). Towards the Competitive Frontier: Strategies for Improving Ethiopia's Investment Climate, unlocking the Power of Women.

Yousefpour, M., Hosseinzadeh, M., Hosseinzadeh, H., Talebnejad, S. R., \& Akbari, Y. (2012). Investigate the factors Women's Entrepreneurship in the country's economic development, entrepreneurship and business management knowledge -based National Conference, Mazandaran University.

Zororo, M. (2011). Characteristics and Motivation in Female Entrepreneurship. Case of Botswana. University of Botswana Journal.
The National Human Resources and Employment Policy for Sri Lanka. Retrieved on 01-2-2016 from http://www. nhrep.gov.lk/images/pdf/nhrep_final.pdf

Resource profile \& statistical of Vavuniya district (2015). District planning secretariat district secretariat Vavuniya

Sri Lanka Labour Force Survey Annual Report (2014).

IFC (2012). Creating jobs in Sri Lanka" a case study role of private sector financial institutions.

Retrieved from http://www.unevoc.unesco. org/e-forum/thesis \%20final.pdf, on 01-02$\underline{2016}$

Retrieved from https://karwenji.wordpress. com/2012/09/01/challenges-facingwomen-owned-s mall-and-microenterprises-in-kenya, on 01-02-2016

Retrieved from International Finance Cooperation- http://www.ifc.org, on 02-022016

Retrieved from International Labour Organization - http://www.ilo.org, on 0202-2016 